\title{
Study of lamellar structures of graft- type fluorinated proton exchange membranes by small-angle X-ray scattering: preparation procedures and grafting degree dependence for fuel application
}

- Tran Duy Tap

- Pham Minh Hien

- Nguyen Hoang Anh

- Luong Tuan Anh University of Science, VNU-HCM

- Luu Anh Tuyen

Center for Nuclear Techniques HCMC

(Received on December $10^{\text {th }} 2014$, accepted on September $23^{\text {rd }} 2015$ )

\section{ABSTRACT}

The variation of lamellar structures of poly(styrenesulfonic acid)-grafted poly (ethylene-co-tetrafluoroethylene) proton exchange membranes dependence on preparation procedures and grafting degree (GD) was investigated by small angle $X$-ray scattering. The detail structures of lamellar including lamellar period $L$, thickness of lamellar crystal $L_{c}$, thickness of lamellar amorphous $L_{a}$, and linear crystallinity $L_{d} L$ were examined by a $1 D$ correlation function.

The lamellar structures were recognized at the grafting step and did not change under the sulfonation process. With $G D \geq 79 \%, L_{c}$ significantly decreased (corresponding to the increase of $L_{a}$ ) and then retained in the GDs of $79-117 \%$. Note that the retained values of $L_{c}, L_{a}$, and linear crystallinity in the GDs of $79-117 \%$ are the origin of high conductivity and mechanical strength of membranes under severe operation conditions for fuel cell applications.

Keywords: small angle $X$-ray scattering, proton exchange membrane, lamellar, $1 D$ correlation function

\section{INTRODUCTION}

Polymer electrolyte membranes (PEMs) have been considered as one of the key components for fuel cell performance because their properties required for fuel cell applications, such as ionic conductance, mechanical strength, and thermal stability, are directly related to their power

generation efficiency and durability under severe operating conditions [1]. The pre-irradiation grafting method, in which polymer substrates are first irradiated using a quantum beam and then immersed in a monomer solution for graft polymerization, is a widely recognized technique 
for the introduction of a new functional grafted polymer phase directly into the polymer substrates while maintaining the substrate's inherent characteristics such as thermal stability, mechanical strength, electronic properties, and crystallinity [2]. Therefore, this irradiation technique has been applied to the preparation of PEMs for fuel cells through the sulfonation of grafted films. Among the many graft-type PEMs, poly(styrenesulfonic acid)-grafted poly(ethyleneco-tetrafluoroethylene) (ETFE-PEM) has been intensively investigated because of its wellbalanced properties such as crystallinity, mechanical strength, thermal/chemical stability, and high proton conductivity, which are required for graft polymerization and fuel cell applications $[3,4]$.

A fundamental understanding of the structure-property relationship of PEMs is a prerequisite for material design that satisfies PEM performance requirements. Therefore, it is important to analyze the hierarchical structures such as the crystalline morphology (lamellar and crystallite), conducting layers consisting of graft polymers (size, shape, and connectivity), and the internal structures of the conducting layers (aggregation of the sulfonic acid groups and water), and the phase separation between the hydrophobic polymer substrates and hydrophilic graft domains [2,5]. Regarding the lamellar stacks, the detail investigations of their structures including the interfacial thickness $\left(\mathrm{L}_{\mathrm{i}}\right)$, which is the size of the boundary between the crystalline and amorphous layers, the thickness of the crystalline $\left(\mathrm{L}_{\mathrm{c}}\right)$ and amorphous layers $\left(\mathrm{L}_{\mathrm{a}}\right)$ in the lamellar stacks are crucial for depth understanding of their effects on the properties of PEMs. There have been several reports concerning the structures of lamellar and their internal structures relating to the ion-conducting layers in ETFE-PEMs using small angle X-ray scattering (SAXS) measurements [5,6]. However, the effects of preparation procedures and grafting degree (GD) on the structures of lamellar stacks have not been considered. Accordingly, in this study, the variation of the structures of the lamellar stacks dependence on preparation procedures and grafting degree (GDs $=0-117 \%$, corresponding to an ion exchange capacity (IEC) range of $0-3.1 \mathrm{mmol} / \mathrm{g}$ were observed using a wide $q$-range observation $\left(q=4 \times 10^{-3}-3 \mathrm{~nm}^{-1}\right)$ in small and ultra-small-angle $\mathrm{X}$-ray scattering (SAXS/USAXS), corresponding to a large Bragg spacing ( $d$-spacing) of $2-1600 \mathrm{~nm}$. The results were compared with the profiles of the precursor original ETFE and polystyrene-grafted ETFE films (Grafted-ETFE), because the grafted PEMs are well-known to retain the crystalline structures and graft polymer phases of the precursor original and grafted films.

\section{METHODS}

\section{Sample preparation}

ETFE-PEMs with GDs of $4.2-117 \%$ were prepared by pre-irradiation grafting of styrene and a subsequent sulfonation reaction, as showed in Fig. 1. Because the detailed preparation method was described in our previous publications, the present study briefly outlines the preparation method as follows. ETFE films with a thickness of $50 \mu \mathrm{m}$ (Asahi Glass Co. Ltd.) were pre-irradiated by ${ }^{60} \mathrm{Co}$ gamma rays with an absorbed dose of $15 \mathrm{kGy}$ under an argon atmosphere and then immersed in a styrene solution at $60^{\circ} \mathrm{C}$. The $G D$ of the grafted-ETFE was determined using the following equation:

$$
G D(\%)=\frac{W_{g}-W_{0}}{W_{0}} \times 100 \%(1)
$$

where $W_{0}$ and $W_{g}$ are the weights of the films before and after the graft polymerization, respectively. The grafted-ETFE was then immersed in $0.2 \mathrm{M}$ chlorosulfonic acid in 1,2dichloroethane at $50{ }^{\circ} \mathrm{C}$ for $6 \mathrm{~h}$. The membrane was washed with pure water at $50{ }^{\circ} \mathrm{C}$ for $24 \mathrm{~h}$ to

\section{Trang 154}


obtain an ETFE-PEM. The IECs of the ETFEPEMs were determined by titration analysis with a standardized $0.01 \mathrm{M} \mathrm{NaOH}$ solution using the following equation:
IEC $($ mmol $/ g)=\frac{0.01 \times V_{\mathrm{NaOH}}}{\text { Dry weight of membrane }}$

where $V_{\mathrm{NaOH}}$ is the consumed volume $(\mathrm{mL})$ of the $0.01 \mathrm{M} \mathrm{NaOH}$ solution.

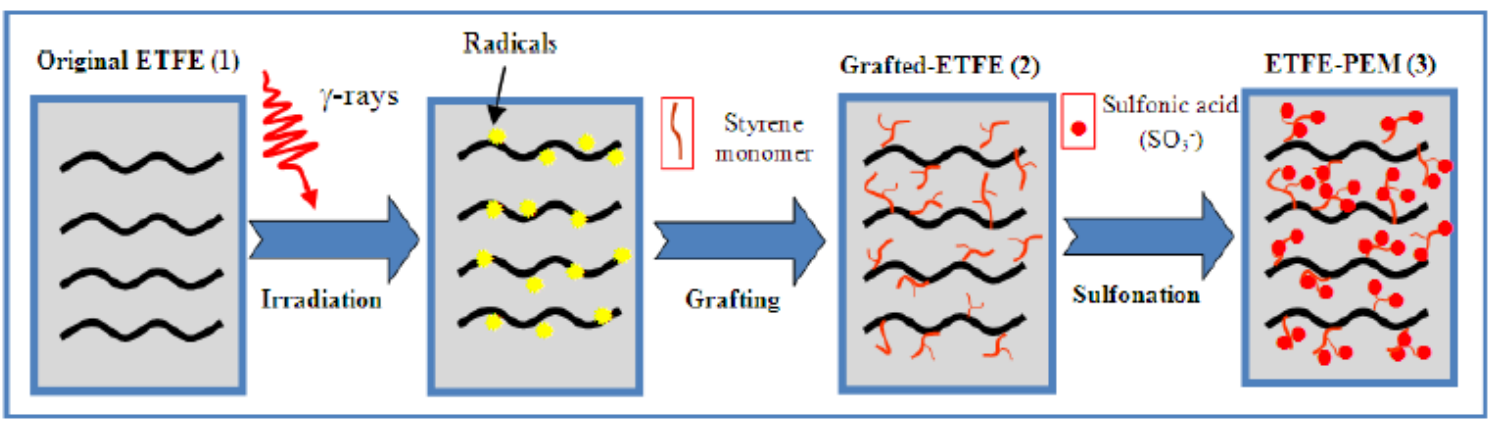

Fig. 1. Radiation-induced graft polymerization of styrene (2) onto an ETFE substrate (1) and the subsequent sulfonation to prepare ETFE-PEM (3).

\section{SAXS measurements}

SAXS measurements were performed using two in-house SAXS spectrometers (NIMSSAXS-II and NIMS-SAXS-III) at the National Institute of Material Science (NIMS) and at USAXS at Super Photon ring-8 GeV (SPring-8), Japan. At NIMS, fine-focus SAXS instruments with X-rays of Mo- $K_{\alpha}\left(\lambda_{\alpha}=0.07 \mathrm{~nm}\right)$ (Rigaku NANO-Viewer, Tokyo, Japan) and $\mathrm{Cr}-K_{\alpha}\left(\lambda_{\alpha}=\right.$ $0.23 \mathrm{~nm}$ ) (Bruker NanoSTAR, Germany) were utilized. The characteristic $K_{\alpha}$-radiation was selected and focused by two-dimensional confocal mirrors and Göbel mirrors for Mo- and Cr-SAXS, respectively. The 2D scattering X-rays were then recorded using a multi-wire gas-filled 2D detector (Bruker, HiStar, Germany). The sample-detector distances in the Mo-SAXS and Cr-SAXS were 35.0 and $105.6 \mathrm{~cm}$, respectively. Therefore, the total $q$-range of the SAXS profiles at NIMS was $q=0.07-3.13 \mathrm{~nm}^{-1}$. Here, $q$ is referred to as the modulus of the scattering vector, equaling $4 \pi \sin \theta / \lambda$, where $2 \theta$ is the scattering angle and $\lambda$ is the wavelength of the incident X-rays. At SPring-8, SAXS measurements were performed by USAXS at beam line BL19B2 using an incident X-ray energy of $18 \mathrm{keV}(\lambda=0.0688 \mathrm{~nm})$. The scattering $\mathrm{X}$-rays were detected by the two-dimensional hybrid pixel array detectors, PILATUS-2M (pixel apparatus). The sample-detector distance was 42 $\mathrm{m}$, corresponding to a $q$-range of $0.004-0.242$ $\mathrm{nm}^{-1}$. Thus, both pinhole SAXS measurements at NIMS and SPring-8 were carried out to cover a wide $q$-range $\left(q=0.004-3.13 \mathrm{~nm}^{-1}\right)$. The SAXS intensities were circularly averaged and corrected for the absorption of the sample and the instrument background. The absolute SAXS intensity was corrected using the secondary standard of glassy carbon.

\section{RESULTS AND DISCUSSION}

The variation of lamellar structure by preparation procedures

Fig. 2 shows the SAXS profiles of the grafted-ETFE films with GDs of 0-117 \% and the corresponding ETFE-PEMs with IECs of $0-3.1 \mathrm{mmol} / \mathrm{g}$ in the $q$-range of $4 \times 10^{-3}-3.0 \mathrm{~nm}^{-1}$. For the grafted-ETFE films, the SAXS profiles exhibited clear peaks in the $G D$ range of 4.2-19 $\%$ at approximately $q=0.247-0.329 \mathrm{~nm}^{-1}$ corresponding to a $d$-spacing of $19.1-25.4 \mathrm{~nm}$, 
which became broader shoulder-like peaks at higher GDs (34-117\%) at $q=0.220-0.231 \mathrm{~nm}^{-1}$ with a $d$-spacing of $27.1-28.5 \mathrm{~nm}$. The maximum peaks around $\mathrm{q}=0.220-0.329 \mathrm{~nm}^{-1}$ originated from a lamellar structure, as previously reported $[5,6]$. For the ETFE-PEMs, the SAXS profiles were almost the same as those of the graftedETFE in the entire q-range. In order to gain a detail insight of lamellar structure, a onedimensional correlation function $\gamma(r)$ was used to determine the average thickness of the crystalline $\left(\mathrm{L}_{\mathrm{c}}\right)$, the amorphous layers $\left(\mathrm{L}_{\mathrm{a}}\right)$, and the interfacial thickness $\left(\mathrm{L}_{\mathrm{i}}\right)$ within the lamellar stacks. The correlation function in its most simple sense is the Fourier inversion of the Lorentz-corrected scattering intensity as a function of $\mathrm{q}$ as showed in the flowing equation [7]:

$$
\gamma(r)=\frac{\int_{0}^{\infty} I(q) q^{2} \cos (q r) d q}{\int_{0}^{\infty} I(q) q^{2} d q}
$$

where $\mathrm{r}(\mathrm{nm})$ presents the correlation distance in real space, normal to the lamellar and I(q) is the experimental scattering intensity function. The function presents the probability of finding electron density as a function of distance $r$, within the material from an origin or zero position which, in our case, can be taken as being the center of a single crystalline lamellar based on the fact that the linear crystallinity $\left(\mathrm{L}_{\mathrm{c}} / \mathrm{L}\right)$ of the films in the entire GD is lower than $50 \%$.
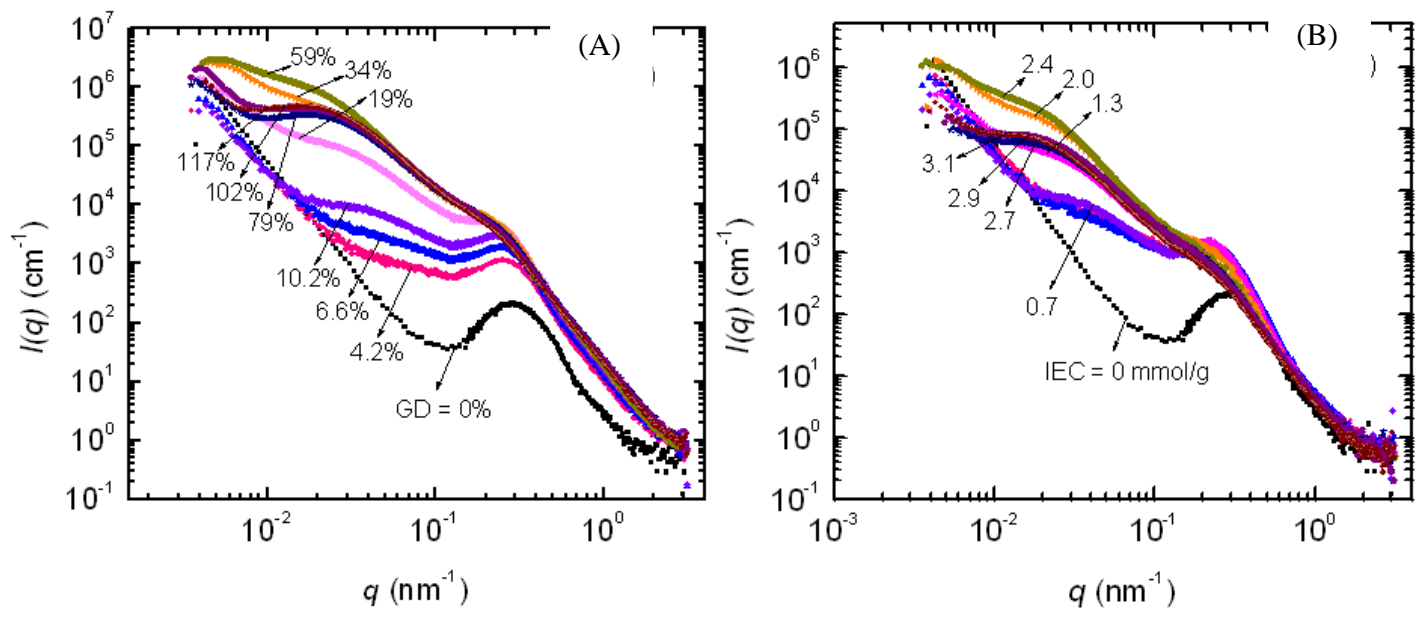

Fig. 2. (A) SAXS profiles of the grafted-ETFE with $G D s$ of $0-117 \%$ and corresponding to

(B) the ETFE-PEMs with IECs of $0-3.1 \mathrm{mmol} / \mathrm{g}$.

Fig. 3 shows the 1D correlation function of the pristine ETFE, grafted-ETFE, and ETFEPEM with GD $=6.6 \%$. It can be seen that the lamellar morphology of the precursor film (i.e., the pristine ETFE) has a sharp distribution of lamellar thickness. After grating (grafted-ETFE) and subsequence sulfonation of the grafted film (ETFE-PEM), the correlation function plots of both films are almost the same but wider distribution of lamellar thickness than the pristine film. The results indicate that the grafting process but not the sulfonation one induces the noticeable changes in the lamellar stacks. These features can be used for gaining a detail insight of the lamellar stacks dependence on preparation procedures. As showed in Fig. 3, the long period L (i.e., the correlation distance between the two adjacent lamellar crystals) can be estimated from twice of the position point of the minimum $\left(\mathrm{L}_{\min }\right)$ or from the position of the maximum in the correlation

\section{Trang 156}


function curve $\left(\mathrm{L}_{\max }\right) . \quad \mathrm{L}_{\min }$ presents the correlation distance between the center of the crystal and the adjacent amorphous region, while $\mathrm{L}_{\max }$ presents the correlation distance between the centers of two adjacent crystals (Figure 4). For an ideal two phase system, $\mathrm{L}_{\max }=2 \mathrm{~L}_{\min }$ but, for most polymer, the thickness distribution of the crystals and amorphous regions are not the same and are usually broad, which results in $\mathrm{L}_{\max } \neq$ $2 \mathrm{~L}_{\text {min }}$. Thus, we assume that the interfacial thickness (or diffuse boundary thickness) presents in the samples (Figure 4) and can be estimate by the following equation:

$$
L_{i}=L_{c}-L_{c 0}
$$

where $\mathrm{L}_{\mathrm{c} 0}$ is the thickness of the core for all lamellae. In the Figure 3, $\mathrm{L}_{\mathrm{c}}$ can be estimated as an intersection between the straight line extended from the self-correlation region and the base line. In addition, $\mathrm{L}_{\mathrm{c} 0}$ can be determined as a position of lower limit of the straight line. The results of above parameters are presented in the Table 1.

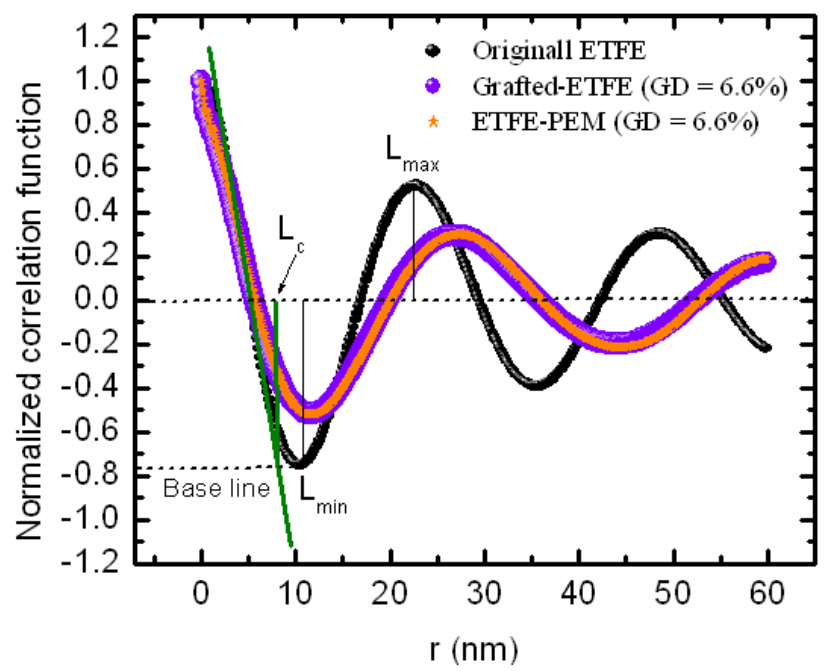

Fig. 3. The 1D correlation function of the pristine ETFE, grafted-ETFE, and ETFE-PEM with GD $=6.6 \%$.

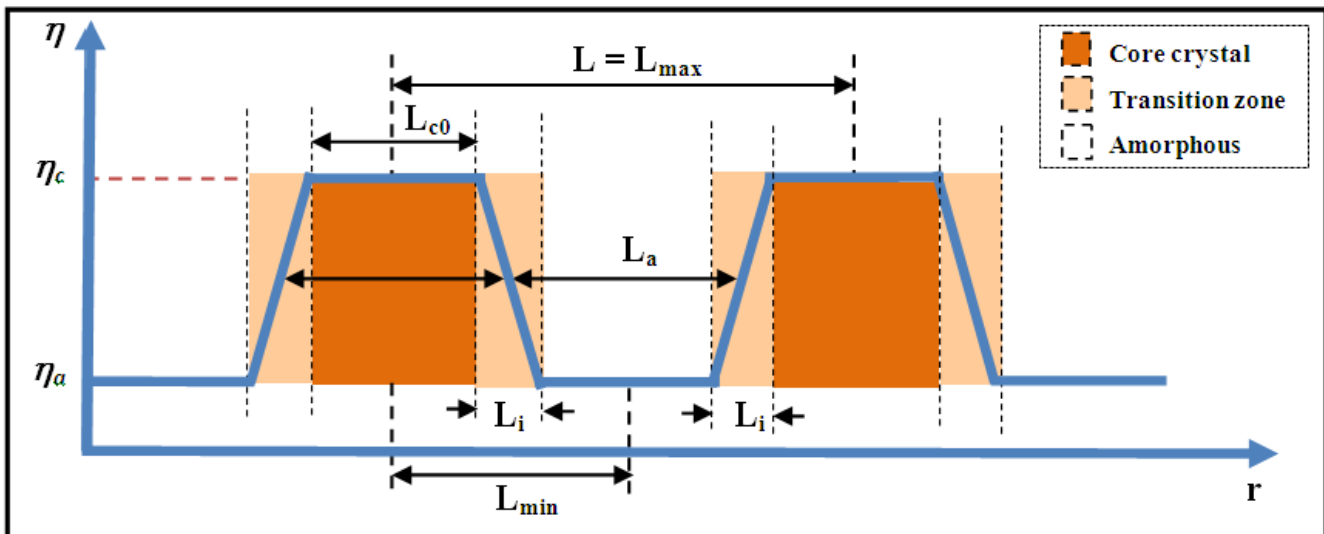

Fig. 4. Electron density distribution $\eta(r)$ and the detail insight of the lamellar stack. $\eta_{c}$ and $\eta_{c}$ are the average electron density of the lamellar crystal and lamellar amorphous, respectively. 
Table 1 shows the values of $\mathrm{L}, \mathrm{L}_{\mathrm{c}}, \mathrm{L}_{\mathrm{a}}, \mathrm{L}_{\mathrm{c} 0}, \mathrm{~L}_{\mathrm{i}}$, and the linear crystallinity $\left(\mathrm{L}_{\mathrm{c}} / \mathrm{L}\right)$. The values of $\mathrm{L}$ for the grafted-ETFE and ETFE-PEM are 27.0 and $27.6 \mathrm{~nm}$, respectively which is higher than those of the pristine ETFE $(\mathrm{L}=22.0 \mathrm{~nm})$ even at a low $\mathrm{GD}=6.6 \%$. The similar trend was also recognized for $L_{a}$, namely the value of $L_{a}$ for the pristine ETFE is $13.9 \mathrm{~nm}$ and increases to 18.5 and $19.1 \mathrm{~nm}$ for the grafted-ETFE and ETFEPEM. The results clearly indicate that some of the PS grafts were introduced in the lamellar amorphous regions (as illustrated in Figure 5) resulting in the expansion of $\mathrm{L}$ after the grafting and sulfonation processes. As a result, the decrease of the linear crystallinity from the pristine ETFE (36.8\%) to the grafted-ETFE $(31.5 \%)$ and ETFE-PEM $(30.8 \%)$ as presented in Table 1 originated from the increase of $L_{a}$. Note that all parameters showed in Table 1 for grafted-ETFE and ETFE-PEM are almost similar suggesting that the sulfonation did not induce a noticeable change in the lamellar structure.

Table 1. Values of $\mathrm{L}, \mathrm{L}_{\mathrm{c}}, \mathrm{L}_{\mathrm{a}}, \mathrm{L}_{\mathrm{c} 0}, \mathrm{~L}_{\mathrm{i}}$, and crystallinity of the pristine ETFE, grafted-ETFE, and ETFE-PEM with GD $=6.6 \%$.

\begin{tabular}{ccccccc}
\hline \hline Samples & $\mathbf{L}(\mathbf{n m})$ & $\mathbf{L}_{\mathbf{c}}(\mathbf{n m})$ & $\mathbf{L}_{\mathbf{a}}(\mathbf{n m})$ & $\mathbf{L}_{\mathbf{c} \mathbf{0}}(\mathbf{n m})$ & $\mathbf{L}_{\mathbf{i}}(\mathbf{n m})$ & Crystallinity $(\boldsymbol{\%})$ \\
\hline Original ETFE & 22.0 & 8.1 & 13.9 & 6.1 & 2.0 & 36.8 \\
$\begin{array}{c}\text { Grafted-ETFE } \\
(\mathrm{GD}=6.6 \%)\end{array}$ & 27.0 & 8.5 & 18.5 & 6.5 & 2.0 & 31.5 \\
ETFE-PEM $(\mathrm{GD}=6.6 \%)$ & 27.6 & 8.5 & 19.1 & 6.4 & 2.1 & 30.8 \\
\hline
\end{tabular}

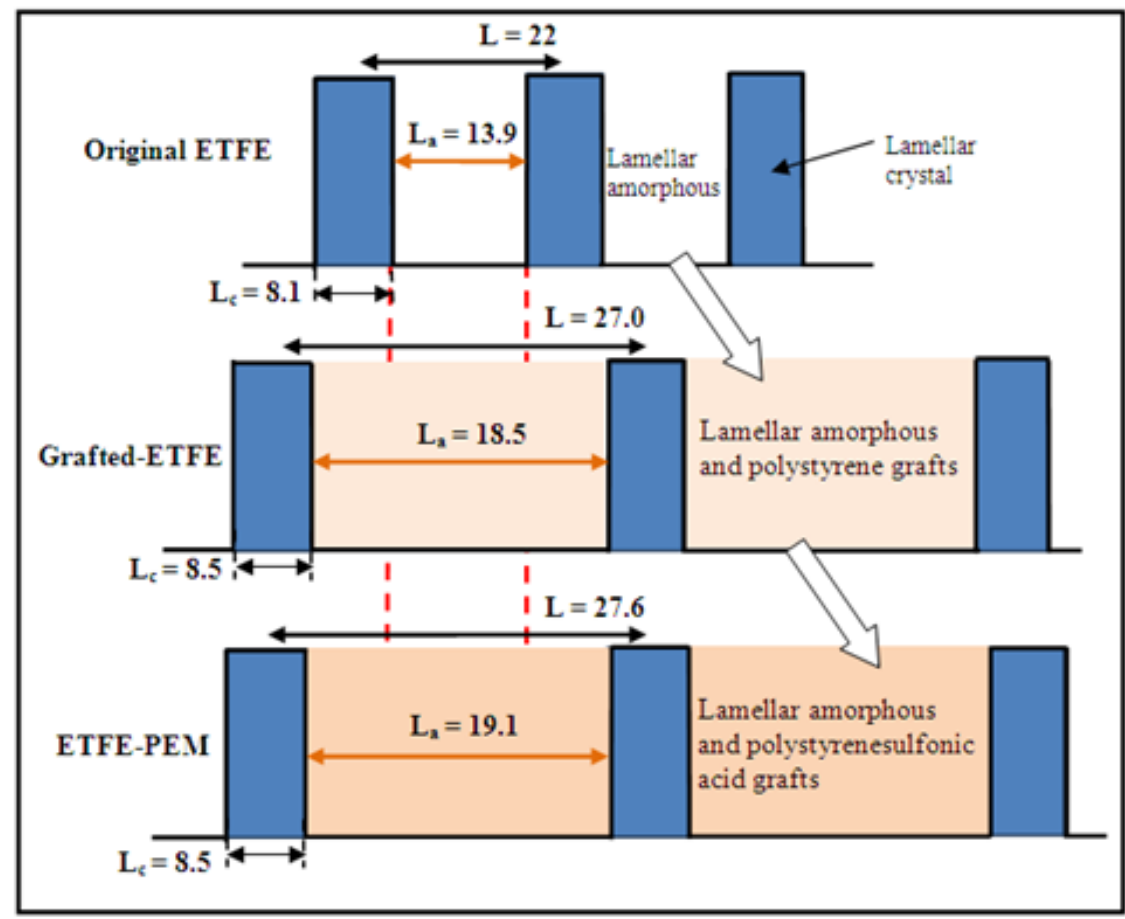

Fig. 5. Illustration of the changes of lamellar structures of the pristine ETFE, grafted-ETFE, and ETFE-PEM with $\mathrm{GD}=6.6 \%$ dependence on the grafting and subsequent sulfonation processes.

\section{Trang 158}


The variation of lamellar structure by the grafting degree

Table 2 shows the values of $\mathrm{L}, \mathrm{L}_{\mathrm{c}}, \mathrm{L}_{\mathrm{a}}$, and crystallinity of grafted-ETFE and ETFE-PEM with GD $=0-117 \%$ (The plots of 1D correlation function dependence on the GD did not show in the text). In addition, the curvatures of the 1D correlation function of the films at higher GD result in the difficulty for determine the $\mathrm{L}_{\mathrm{c} 0}$ and $\mathrm{L}_{\mathrm{i}}$. Thus, the values of $\mathrm{L}_{\mathrm{c} 0}$ and $\mathrm{L}_{\mathrm{i}}$ were not presented in Table 2. As showed in Table 2 for the grafted-ETFE, the value of $\mathrm{L}_{\mathrm{c}}=8.1-7.1 \mathrm{~nm}$ slightly decreased in the range of GD $=0-34 \%$ and significantly dropped at GD $=59 \%(2.7 \mathrm{~nm})$ and then further decreased to $1.5 \mathrm{~nm}$ at GD $=79$ $\%$ and final retained in the GD $=79-117 \%$. Because $L$ is the sum of $\mathrm{L}_{c}$ and $\mathrm{L}_{\mathrm{a}}$ and $\mathrm{L}$ did not change in the entire GD (GD $=4.2-117 \%$ ), the values of $\mathrm{L}_{\mathrm{a}}$ changed with the opposite trends to that of $L_{c}$ as showed in Table 2. The thickness of lamellar crystal dramatically decreased at higher GD (> $19 \%)$ as the resulting from the deterioration of the lamellae during the grafting processes resulting in the expansion of $\mathrm{L}_{\mathrm{a}}$ and the decrease of crystallinity with the increase of GD.

Table 2. Values of $\mathrm{L}, \mathrm{L}_{\mathrm{c}}, \mathrm{L}_{\mathrm{a}}$, and crystallinity (\%) of the grafted-ETFE and ETFE-PEM with GD $=0-117 \%$. The dimension of $\mathrm{L}, \mathrm{L}_{\mathrm{c}}$, and $\mathrm{L}_{\mathrm{a}}$ is $\mathrm{nm}$.

\begin{tabular}{|c|c|c|c|c|c|c|c|c|}
\hline \multirow{2}{*}{$\begin{array}{l}\text { GD } \\
(\%)\end{array}$} & \multicolumn{4}{|c|}{ Grafted-ETFE } & \multicolumn{4}{|c|}{ ETFE-PEM } \\
\hline & $\mathbf{L}$ & $\mathbf{L}_{\mathbf{c}}$ & $\mathbf{L}_{\mathbf{a}}$ & Crystallinity (\%) & $\mathbf{L}$ & $\mathbf{L}_{\mathbf{c}}$ & $\mathbf{L}_{\mathrm{a}}$ & Crsytallinity (\%) \\
\hline 0 & 22.0 & 8.1 & 13.9 & 36.8 & 22.0 & 8.1 & 13.9 & 36.8 \\
\hline 4.2 & 26.0 & 8.5 & 17.5 & 32.7 & 25.6 & 8.6 & 17.0 & 33.6 \\
\hline 6.6 & 25.3 & 8.5 & 16.8 & 33.6 & 25.9 & 8.5 & 17.4 & 32.8 \\
\hline 8.8 & 25.5 & 7.9 & 17.6 & 31.0 & 27.6 & 8.5 & 19.1 & 30.8 \\
\hline 10.2 & 25.9 & 8.6 & 17.3 & 33.2 & 25.4 & 8.6 & 16.8 & 33.9 \\
\hline 19.0 & 25.4 & 7.1 & 18.3 & 28.0 & 26.6 & 7.6 & 19.0 & 28.6 \\
\hline 34.0 & 25.1 & 7.2 & 17.9 & 28.7 & 26.0 & 8.2 & 17.8 & 31.5 \\
\hline 59.0 & 25.7 & 2.7 & 23.0 & 10.5 & 22.9 & 2.9 & 20.0 & 12.7 \\
\hline 79.0 & 25.8 & 1.5 & 24.4 & 5.6 & 26.2 & 1.6 & 24.6 & 6.0 \\
\hline 102.0 & 25.9 & 1.7 & 24.2 & 6.5 & 25.7 & 1.6 & 24.1 & 6.3 \\
\hline 117.0 & 25.3 & 1.4 & 23.9 & 5.7 & 25.3 & 1.9 & 23.4 & 7.5 \\
\hline
\end{tabular}

In the entire $\mathrm{GD}$, the values of the $\mathrm{L}, \mathrm{L}_{\mathrm{c}}, \mathrm{L}_{\mathrm{a}}$, and crystallinity of ETFE-PEM changed the same trends to those of the grafted-ETFE. The results indicate that the sulfonation process did not cause the noticeable changes of the lamellar structures with the changes of the GD. In other words, the lamellar structure was significant changed and really recognized only at the grafting process.

Recently, we reported the relative humidity (RH) dependence of the electrochemical and mechanical properties of ETFE-PEMs in a wide ion exchange capacity (IEC) range [3]. The results showed that ETFE-PEMs have proton conductivities that are less dependent on the RH. Namely, ETFE-PEMs with IECs $>2.7 \mathrm{mmol} / \mathrm{g}$ exhibited higher conductivity (> $0.009 \mathrm{~S} / \mathrm{cm}$ ) under $30 \% \mathrm{RH}$ and showed compatible tensile strengths of approximately $10 \mathrm{MPa}$ at $100 \% \mathrm{RH}$ and $80{ }^{\circ} \mathrm{C}$. Thus, the retained lamellae crystal even at very high GD (GD > $79 \%$, IEC > 2.7 $\mathrm{mmol} / \mathrm{g}$ ) should be one of the most original 
reasons for the high mechanical strength and high proton conductivity of membranes under severe operation conditions.

\section{CONCLUSION}

The detail lamellar structures including lamellar period L, thickness of lamellar crystal $\mathrm{L}_{\mathrm{c}}$, thickness of lamellar amorphous $\mathrm{L}_{\mathrm{a}}$, and linear crystallinity $\mathrm{L}_{\mathrm{c}} / \mathrm{L}$ of ETFE-PEM were examined by a 1D correlation function from the small angle X-ray profiles in the wide GDs = $0-117 \%$ (IECs $=0-3.1 \mathrm{mmol} / \mathrm{g})$. The lamellar structures were recognized at the grafting step and did not change under the sulfonation process. With GD $\geq 79 \%, \mathrm{~L}_{\mathrm{c}}$ significantly decreased (corresponding to the increase of $\mathrm{L}_{\mathrm{a}}$ ) and then retained in the GDs of $79-117 \%$. Note that the retained values of $\mathrm{L}_{\mathrm{c}}, \mathrm{L}_{\mathrm{a}}$, and linear crystallinity in the GDs of $79-117 \%$ are the origin of high conductivity and mechanical strength of membranes under severe operation conditions for fuel cell applications.

\section{Nghiên cứu cấu trúc lamellar của màng trao đổi proton fluor hóa tạo dạng ghép sử dụng phương pháp tán xạ tia X góc nhỏ: sự phụ thuộc vào quy trình chế tạo mẫu và mức độ ghép mạch hướng ứng dụng cho pin nhiên liệu}

- Trần Duy Tập

- Phạm Minh Hiền

- Nguyễn Hoàng Anh

- Lương Tuấn Anh

Trường Đại học Khoa học Tự nhiên, ĐHQG-HCM

- Lưu Anh Tuyên

Trung Tâm Hạt Nhân Tp.HCM

\section{TÓM TÁT}

Sự thay đổi cấu trúc lamellar của màng dẫn proton ETFE-PEM theo quy trình chế tạo mẫu và mức độ ghép mạch bức xạ (GD) được nghiên cứu bởi kỹ thuật tán xạ tia $X$ góc nhỏ. Thông tin chi tiết cấu trúc lamellar bao gồm khoảng cách lamellar $L$, bề dày lamellar tinh thể $L_{c}$, bề dày lamellar vô định hình $L_{a}$, và phần trăm tinh thể $L_{d} L$ được xác định bằng hàm tương quan một chiều. Cấu trúc lamellar chỉ thay đổi tại bước ghép mạch bức xạ và không phụ thuộc vào quá trình lưu Từ khoá: tán xạ tia $X$ góc nhỏ, màng dẫn proton, lamellar, hàm tương quan một chiều huỳnh hoá. Với $G D \geq 79 \%$, giá trị $L_{c}$ giảm xuống mạnh mẽ (tương ứng với sự tăng lên mạnh mẽ của $L_{a}$ ) nhưng sau đó không đổi trên toàn giá trị $G D=79-117 \%$. Cần nhấn mạnh rằng sự không giảm giá trị của $L_{c}, L_{a}$, và phần trăm tinh thể trên toàn giá trị $G D=$ 79-117\% là nguồn gốc của việc dẫn proton cao, tính chất co học tốt của màng hoạt động tại điều kiện khắt khe để ứng dụng cho pin nhiên liệu. 


\section{REFERENCES}

[1]. R. Borup, J. Meyers, B. Pivovar, Y.S. Kim, R. Mukundan, N. Garland, D. Myyers, M. Wilson, F. Garzon, D. Wood, P. Zelenay, P. Zelenay, K. More, K. Stroh, T. Zawodzinski, J. Boncella, J.E. McGrath, M. Inaba, K. Miyatake, M. Hori, K. Ota, Z. Ogumi, S. Miyata, A. Nishikata, Z. Siroma, Y. Uchimoto, K. Yasuda, K. Kimjima, N. Iwashita, Scientific aspects of polymer electrolyte fuel cell durability and degradation, Chemistry Review, 107, 39043951 (2007).

[2]. M.M. Nasef, E.A. Hegazy, Preparation and applications of ion exchange membranes by radiation induced-graft polymerization of polar monomer onto non-polar fimls, Progress Polymer Science, 29, 499-561 (2004).

[3]. T.D. Tap, S. Sawada, S. Hasegawa, Y. Katsumura, Y. Maekawa, Poly(ethylene-cotetrafluoroethylene) (ETFE)-based grafttype polymer electrolyte membranes with different ion exchange capacities with various IEC: Relative humidity dependence for fuel cell applications, Journal of Membrane Science, 447, 19-25 (2013).
[4]. J. Chen, M. Asano, M. Yoshida, Y. Maekawa, Suitability of some fluoropolymer used as base films for preparation of polymer electrolyte fuel cell membranes, Journal of Membrane Science, 277, 249-257 (2006)

[5]. T.D. Tap, S. Sawada, S. Hasegawa, K. Yoshimura, Y. Oba, M. Ohnuma, Y. Katsumura, Y. Maekawa, Hierachical structure-property relationships in graft-type fluorinated polymer electrolyte membranes using small- and ultrasmall-angle X-ray scattering analysis, Macromolecules, 47, 2373-2383 (2014).

[6]. K. Jokela, R. Serimaa, M. Torkkeli, F. Sundholm, T. Kallio, G. Sundholm, Effect of the initial matrix material on the structure of radiation-grafted ion-exchange membranes: Wide-angle and small-angle Xray scattering studies, Journal of Polymer Science: Polymer Physics Edition, 40, 15391555 (2002).

[7]. G.R. Strobl, M. Schneider, Direct evaluation of the electron density correlation function of partially crystalline polymers, Journal of Polymer Science: Polymer Physics Edition, 18, 1343-1359 (1980). 